\title{
Impact of fiscal policy on economic growth: A comparison between Singapore and Sri Lanka
}

\author{
Sriyalatha M.A.K. ${ }^{1}$ and Torii $\mathrm{H}^{2}{ }^{2}$ \\ University of Sri Jayewardenepura, Sri Lanka ${ }^{1}$, Meijo University, Japan ${ }^{2}$ \\ kumuduni@sjp.ac.lkํㅗㄱ.htorii@meijo-u.ac.jp²
}

\begin{abstract}
The purpose of this paper is to examine the long-term impacts of fiscal variables on economic growth in Singapore and Sri Lanka from 1972 to 2017. Autoregressive Distributed Lag (ARDL)-ECM approach and some diagnostic and specification tests were employed to determine the impact of fiscal variables on economic growth on time series data. The results confirm that government expenditure, government revenue and investment expenditure positively and significantly affect in Singapore as well as Sri Lanka's economic growth in the long run. This result is consistence with the theory of Keynesian views. Moreover, the Toda-Yamamoto's Granger causality results reveal that there is bidirectional causality between inflation rate and economic growth in Singapore. Further, the results show that bidirectional causality relationship between investment expenditure and economic growth in Sri Lanka. Grounded on the premises that there are little or no studies on the impact of fiscal variables on Singapore and Sri Lankan economy with more recent data., this paper provides new evidence on the potential effect of fiscal variables on Singapore's and Sri Lankan economic growth over the last four decades.
\end{abstract}

Keywords: Economic growth, fiscal policy, ARDL, Toda-Yamamoto's Granger causality test, Singapore and Sri Lanka

Copyright: (C) 2019 Sriyalatha M.A.K. and Torii H. This is an open access article distributed under the Creative Commons Attribution License, which permits unrestricted use, distribution, and reproduction in any medium, provided the original work is properly cited.

Funding: The Authors are grateful to the University of Meijo, Japan for granting funds to carry out this research under the postdoctoral fellowship plan.

Correspondence: kumuduni@sjp.ac.lk

ORCID of authors: (D) https://orcid.org/0000-0003-2382-286X

DOI: http://doi.org/10.4038/kjm.v8i1.7559 


\section{Introduction}

The impact of government expenditure on economic growth has become as an interesting and important research area in both developing and developed economies. Over the last decades, researchers have built up various arguments about the relationship between government expenditure and economic growth. Out of different theories, Keynesian approach (Keynes, 1936) is the most popular among researchers. It states that public expenditure is an exogenous policy variable and it causes the changes in aggregate output level in the short run. Further, Keynes pointed out that increase in expenditure causes to accelerate the economic growth. Therefore, Keynesian theory suggests that government intervention through fiscal policies plays a vital role in the economic development process. Meantime, it proposes that the causal relationship between public expenditure and aggregate level of output runs from expenditure to output level of the economy.

Another theory formulated by Wagner (1883) indicates that there is a long run trend for government expenditure to rise as per capita income increases and increase in government expenditure is an expected result of economic growth. Wagner underlined that the economic growth as the fundamental determinant of public sector growth. Therefore, it posits that the causal relationship between economic growth and government expenditure runs from income to expenditure. Empirical studies on government expenditure and economic growth has been highly debating in recent years in both developing as well as developed countries. The most analysis revealed mixed outcomes. Results of some developed countries show that higher government expenditure leads to higher economic growth (Liu et al., 2008), while others do not exhibit such a relationship. Devarajan et al., (1996) show that the negative significant long run relationship among capital expenditure and economic growth in Nigeria.

This study chooses one country from high-income nation and one from lower middle-income nation. Two countries; Singapore and Sri Lanka are selected based on few similarities; such as both countries are located in Asia Pacific region. Sri Lanka became independent on 4 February 1948 while On 9 August 1965, Singapore officially gained sovereignty. Singapore also has high demographic development compared to Sri Lanka today though both countries were about even in 1960s. There is no big difference in government expenditure as a percentage of Gross Domestic Product (GDP) in both countries.

The Singapore economy grew by 3.6 per cent in the fourth quarter in 2017, moderating from the 5.5 per cent growth in the previous quarter. Also its annual real GDP growth rate was 3.6 per cent and an improvement from the 2.4 per cent growth in 2016. All major sectors reported positive growth rate in 2017, with the exception of the construction sector. The manufacturing and finance $\&$ insurance sectors were the key contributors to overall GDP growth in Singapore. The economy of Singapore is a highly developed free - market economy. Singapore's GDP was $\$ 311.3$ billion in 2017. Government spending in Singapore has climbed since the start of the global financial crisis, from around $15 \%$ of GDP in 2008 to $17 \%$ in 2012. The government's total expenditure as a percentage of GDP ranks among the lowest globally. The total population in 2017 was 56.1 million. Singapore gross government debt as percentage of GDP in 
2017 is $105.7 \%$. Due to strong economic conditions, the Singapore government has been able to maintain both the tax rate and the government expenditure at low level and yet generate healthy budget surpluses year after year. The expected overall budget surplus of $\mathrm{S} \$ 9.61$ billion (Singapore Dollars $=\mathrm{S} \$$ ) for the financial year 2017, which estimated as 2.1 per cent of GDP, is higher than in 2016's S\$6.12 billion. Singapore is a highincome economy with a gross national income of US\$52,600 per capita, as of 2017. In the decades after independence, it rapidly developed from a low-income country to a high- income country (Economic Survey of Singapore (2017).

Sri Lanka is a lower middle-income country and population is about 21.4 million. In 2017 per capita GDP is $\$ 4,065$. The economic liberalization reforms were introduced in 1977 in Sri Lanka and the period following the reforms has recorded moderately high economic growth rate but not steady. Thirty years of internal conflict was ended in 2009, thereafter the economy has grown on average at a rate of 5.8 per cent a year. Though Sri Lanka's overall economic conditions have been relatively high, economic growth has not been steady, reflecting the impact of large number of domestic and international economic challengers. Despite the challenges arising from both domestic and external fronts, the Sri Lankan economy grew at a moderate level of 4.5 per cent in 2016 compared to the growth of 5 per cent in 2015. Among domestic challengers, the internal conflict can be seen as an important and it has seriously affected government spending as well as taxation decision especially the late 1980s. The government revenue collection as a percentage of GDP in 1996 was 19 per cent and 20 years later in 2016 it was only 14.3 per cent. The revenue collection increased by 1.0 percentage point as a share of GDP in 2016 compared with 2015. Meanwhile, budget deficit also decreased from7.6 to 5.4 in 2016.In 1996 it was stood at 9.4 percent and the notable increase in the budget deficit was reported in 2001. It was about 10.8 per cent. Meantime, recurrent expenditure as a percentage of GDP declined to 14.8 per cent in 2016 from 15.5 per cent in 2015. Capital expenditure as a percentage of GDP declined in 2016 to 4.9 per cent from 5.4 per cent in 2015. Sri Lanka's gross government debt as percentage of GDP in 2017 is $75.5 \%$ (Central Bank Annual Report, 2016).

\section{Identification of the Research Problem}

Fiscal strength is an essential requirement for achieving overall macroeconomic stability and economic growth. Greater fiscal deficit have also directed to a deterioration of almost all aspects of the economy such as GDP growth rate, interest rate, current account deficit, public debt, inflation etc. If the government revenue of the country is not sufficient to achieve macroeconomic objectives with persistent budget deficit, government needs to borrow money from different sources. Therefore, the government needs to pay the attention on debts and especially for foreign sources of funds or impose more taxes on the general public. According to previous research findings on spending and economic growth, indicates that the results of higher borrowings or increasing taxes show a severe impact on the economic growth. The Keynesian thought of macroeconomics proposes that higher government spending accelerates economic growth. The following figures exhibit the behavior of (figure 1 and 2) Expenditure as a percentage of GDP and GDP growth rates among two countries. We can observe the identical behavior and fluctuations among these two macroeconomics variables in both 
countries. Sri Lanka's government expenditure as a percentage of GDP is always greater than that of Singapore while economic growth rate is lower than the Singapore. From the data, it can be seen that Singapore has strong and stable growth GDP among ASEAN countries. Sri Lanka reports always budget deficit as a percentage of its GDP. The huge and persistent fiscal deficits stimulated considerable concerns about sustainability of the economic growth. Many studies reveal that the large and persistent deficit reduces economic growth (Romer, 2001).

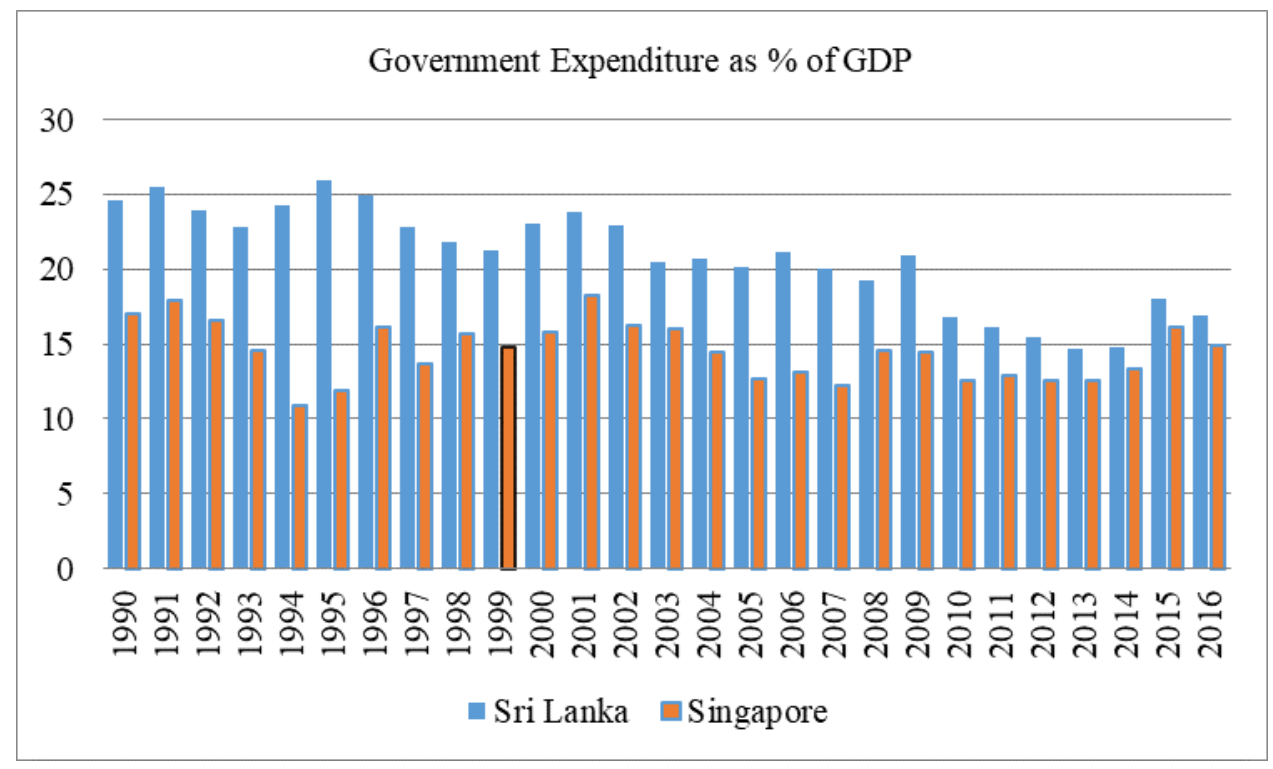

Figure 1 Government Expenditure as a Percentage of GDP in Sri Lanka and Singapore from $1990-2016$

Source: www.adb.org/statistics

However, the efficacy of such spending in Asian and Pacific countries remains low researched and documented. In the present paper, an effort is made to fill this gap through an examination of the role of government spending and revenue in promoting economic growth in the context of developed and developing countries in the Asia-Pacific region by using comparatively recent datasets covering the period 1972-2017. Since the study focuses the Asia-Pacific region, two countries namely Singapore and Sri Lanka were selected. Singapore the big developing nation in the region has displayed remarkable growth in the recent years. Although Sri Lankan economy is small compared to Singapore it has shown invariable growth in the past years and is considered as an emerging economy in the region.

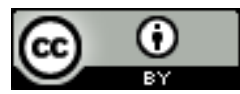




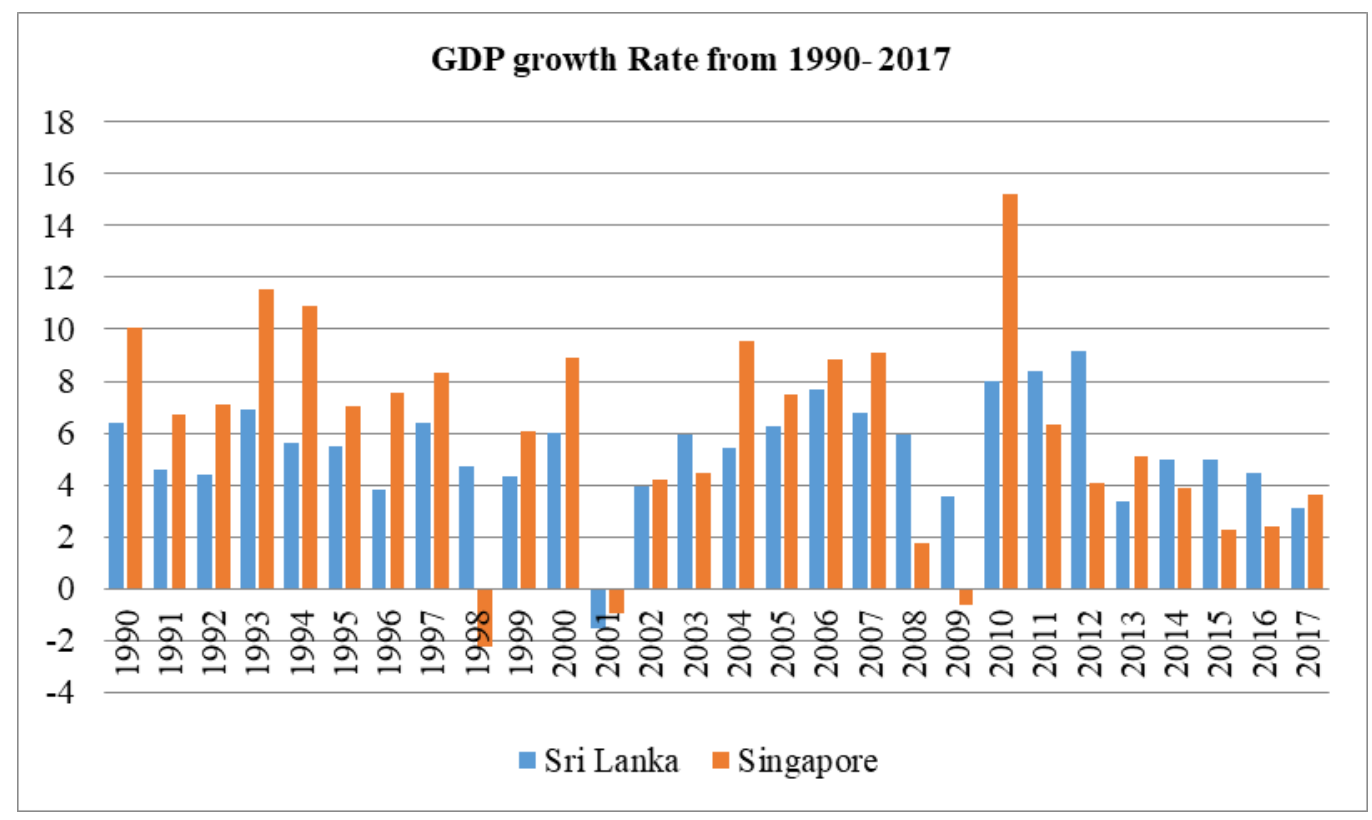

Figure 2 GDP growth rate from 1990 - 2017 in Sri Lanka and Singapore Source: www.adb.org/statistics

\section{Objectives of the Study}

It can be seen that these countries have different patterns in the major composition of expenditure as well as revenue sources during the period of concern. Similar and dissimilar features in expenditure and revenues between Singapore and Sri Lanka need to be elaborated based on their relationship with the macroeconomic conditions. Therefore, this study focuses the following research objectives.

To identify the relationship between the growth rate and fiscal policy variables (government expenditure, defense expenditure and revenue) in Singapore and Sri Lanka

To examine the relationship between other macroeconomic variables (investment expenditure and inflation rate) and economic growth in Singapore and Sri Lanka
To identify the short and long-run relationship among the variables and economic growth in Singapore and Sri Lanka

To identify is the causal relationship between variables in Singapore and Sri Lanka

The remainder of this study is organized as follows: Section 2 details the literature review. Section 3 contains details of the data and methodology employed in the study. Section 4 explains the empirical results of the analysis. Section 5 concludes this paper.

\section{Literature Review}

Earlier, economic literature has among other research fields, paid attention itself with the research studies on the relationships between public expenditure and economic growth. The major findings show that public sector 
expenditure impacts positively on economic growth. Keynes (1936) proposed that increased government expenditures and lower taxes stimulates demand in the economy and pull the global economy out of the depression. Further, Peacock and Wiseman (1961) as well as many other economists have also outlined various theories on public expenditure and economic growth. Solow (1956) argued that the fiscal policy does not have an impact on the growth of national output of the economy. Further, the study has done by Solow (1957) highlighted that fiscal policy measurements supports to improve inefficiencies that might come from the failures of the free market mechanism.

Large number of studies has concentrated on the relation between government expenditure and economic growth in developed as well as developing countries. The results of these studies are different from one study to another and also one country to another. Alexander (1990) employed OLS regression model for 13 Organization for Economic Cooperation and Development (OECD) countries during the period of 1959 1984. The study used panel data and findings indicate that the growth of government expenditure and inflation have negative significant impact on economic growth.

Devarajan et al (1996) examined the relationship between the composition of public expenditure and economic growth using data from 43 developing countries over 20 years. The results suggest that an increase in the share of current expenditure has statistically significant positive impact on economic growth. However, there is a negative relationship between the capital expenditure and economic growth. Surprisingly, the study reveals that when government used in excess capital expenditure, it could be transformed into unproductive. They highlights that governments of the developing country have been misallocating government expenditure in favor of capital expenditures at the expense of recurrent expenditure.

Terasawa and Gates (1998) investigate the relationship between government size and economic growth of 21 industrialized countries. In this study Government size is measured by using government final consumption expenditures and transfer payments. They expect that the relationship between government consumption and GDP growth is positive for developing countries, and negative it for industrialized countries. They also pointed out that transfer payments, and social welfare programs are likely to reduce economic growth for most countries. They revealed that these programs reduce motivation for works and inspire tax prevention activities. The final impact of these activities is reducing economic growth. These expected relationships of the study are consistent with economic performance and government size for the OECD countries.

Liu et al. (2008) examined relationship between public expenditure and economic growth in United States of America. They used aggregate data as well as disaggregate data on national defense expenditure, human resource expenditure, physical resource expenditure, net interest payment and other expenditure in USA from 1947 to 2002. The results revealed that public expenditure leads to a higher economic growth in USA. This result is consistent with the Keynesian theory. They recommend that the US government have to spend more money in human resource expenditure in order to encourage economic growth. 
Sriyalatha (2009) analyzed the relationship between government expenditure and economic growth in Sri Lanka for the period of 1975- 2005 using aggregate and disaggregate data. The results of the cointegration tests show that there is a positive long-run relationship between government expenditure and economic growth. Further the results reveal that the defense expenditure affects negatively long-run economic growth of the country. The causality tests results suggest that defense expenditure and economic growth rate are seen as granger causing government expenditure. Finally, the result concludes that growth rate of the country and growth of defense expenditure both contribute to the growth of public expenditure in Sri Lanka.

Sriyalatha (2012) examined the validity of Wagner's Law for Sri Lanka over the period 1959-2010. The study used a Vector Autoregression (VAR) model and the Granger causality test to identify long run and short run relationship between government expenditure and economic growth. The results of the cointegration tests indicate that there is a long run relationship between public expenditure and economic growth. Although the results reported in this study do not reveal uniformity among the six versions of Wagner's Law, the results show an apparent prevalence of the direction of causality from growth of GDP to public expenditure.

Attari and Javed (2013) explored the relationship among the rate of inflation, economic growth and government expenditure in Pakistan by using the time series data during the period 1980-2010. The study employed aggregate as well as disaggregated data on current expenditure and development expenditure for the analysis. The results of the analysis reveal that there is a long term relationship between rate of inflation, economic growth and government expenditure. The causality test results suggest that the rate of inflation does not affect the economic growth but government expenditures do affect economic growth in Pakistan.

Ono (2014) carried out an empirical study on expenditure-economic growth relationship in the context of vector autoregressive distributed lag (ARDL) model. The new test can be applied when the co-integrating vector is unknown. The study employed annual data from Japan for the period 1960 - 2010. The focus of the study is testing the validity of Wagner's law and the Keynesian view in the case of Japan. The results revealed that Wagner's law applies for Japan and long run equilibrium is asymmetric.

Iulia Rosoiu (2015) assessed the impact of the government revenues and expenditures on the economic growth in Romania over the period 1998 - 2014 by using quarterly data. This study used few variables such as government expenditure, government revenue, inflation rate and interest rate to examine the relationship between economic growth and said variables. The results of the study show that increase in government expenditure causes to higher economic growth. Similarly, higher revenue also leads to higher economic growth rate in Romania. Further, the study reveals that a bidirectional relationship between government revenue and government expenditure.

Hirnissa et al (2009) examine the causal effect and long-run relationships between military expenditure and economic growth in ASEAN-5 countries from the year 1965 - 2006. The results reveal that three countries; Indonesia, Thailand, Singapore exhibit long-run relationship between military expenditure and economic growth. While for the case of Singapore, there is bidirectional causality

Kelaniya Journal of Management | 2019 | Vol. 08 | Issue 01 | Page 43 
between military expenditure and economic growth, for Indonesia and Thailand it is unidirectional from military expenditure to economic growth. For the remaining countries, Malaysia and Philippines, the findings of the results do not indicate meaningful relationship between military expenditure and economic growth.

Mohammadi and Ram (2015) investigate the empirical status of the hypothesis from annual data for six countries over the period of 1960-2008. They find cointegration relationship between Japan and Korea but ail to reject the null hypothesis of no cointegration for Malaysia Philippines Singapore and Thailand. Thus, test results provide a rather weak support in favor of the Wagner's hypothesis.

Phuc Canh (2018) examined the effectiveness of fiscal policy in the relationships with institutional framework and external debt burden for 20 emerging markets. This study is used panel data from 2002 to 2014 . This study revealed that the fiscal policy is necessary to build the basic infrastructure for the economic activities of private sectors. Therefore, the fiscal policy is effective in promoting economic growth. At the same time, this study found that the external debt makes restrictions on the effectiveness of fiscal policy, especially in high indebted countries.

Several studies from various disciplines have studied the factors that drive economic growth in South Asian countries. Meanwhile, inadequate attention paid to the contribution of fiscal policy to economic growth in Singapore and Sri Lanka though these two countries have close relationship each other with respect to different aspects. Thus, this study aims to contribute to the existing literature by examining the impact of fiscal policy on economic growth as well as the short and long-run relationship between fiscal policy variables.

\section{Methodology}

The present study adopts the ARDL bounds testing approach introduced by Pesaran and Shin (1999) and developed by Pesaran et al. (2001) in order to estimate the relationship between economic growth and fiscal policy variables in Singapore and Sri Lanka. This research is used annual data dealing with GDP, government expenditure, revenue, investment, defense expenditure and inflation data in Singapore and Sri Lanka from 1972 to 2017. Annual data were collected from several sources; such as Annual Report of the Central bank of Sri Lanka, www.adb.org/statistics and Asian Development Bank. The long run relationship between economic growth and independent variables can be specified as follows for two counties.

$$
\begin{array}{ccc}
\operatorname{In} Y_{t}=\beta_{0}+\beta_{1} Y 1_{t}+\beta_{2} Y 2_{t}+ & \beta_{3} Y 3_{t}+\beta_{4} Y 4_{t}+\mu_{t} & \text { Model (1) } \\
& (\text { Singapore }) & \\
\operatorname{In} X_{t}=\beta_{0}+\beta_{1} X 1_{t}+\beta_{2} X 2_{t}+\beta_{3} X 3_{t}+\beta_{4} X 4_{t}+\mu_{t} & \text { Model (2) } \\
(\text { Sri Lanka }) &
\end{array}
$$




$$
\begin{array}{ccc}
\operatorname{In} Y_{t}=\beta_{0}+\beta_{1} Y 1_{t}+\beta_{3} Y 3_{t}+ & \beta_{4} Y 4_{t}+\beta_{5} Y 5_{t}+\mu_{t} & \text { Model (3) } \\
& (\text { Singapore) } & \\
\operatorname{In} X_{t}=\beta_{0}+\beta_{1} X 1_{t}+\beta_{3} X 3_{t}+\beta_{4} X 4_{t}+\beta_{5} X 5_{t}+\mu_{t} & \text { Model (4) } \\
& (\text { Sri Lanka) }
\end{array}
$$

Where,

$\ln Y$ and $\operatorname{In} X=$ the natural $\log$ of real GDP in Singapore and Sri Lanka, respectively

$Y 1$ and $X 1=$ the natural $\log$ of Consumer Price Index in Singapore and Sri Lanka, respectively

$Y 2$ and $X 2=$ the natural $\log$ of government expenditure in Singapore and Sri Lanka, respectively

$Y 3$ and $X 3=$ the natural log of government revenue in Singapore and Sri Lanka, respectively $Y 4$ and $X 4=$ the natural $\log$ of Investment expenditure (proxied by gross fixed capital formation) in Singapore and Sri Lanka, respectively

$Y 5$ and $X 5=$ the natural log of defense expenditure in Singapore and Sri Lanka, respectively.

Different investigation methods are available in econometric literature to test the long-run equilibrium between variables of a model. Johansen and Juselius (1990), Engle and Granger (1987), and maximum likelihood test (suggested by Johansen, 1988; Johansen, 1991) are most widely applied by researchers. ARDL technique provides several benefits; among them, first; this approach is facilitated to accommodate small sample sizes while maintaining reliability. Second, it is not requirement of all variables to be integrated of the same order to apply ARDL technique. In case, variables of the model are integrated of different orders, I (1), I (0) or both, it estimate the short- and longrun parameters simultaneously. The approach will however crash in the presence of I (2) series. Third, this methodology supports in eliminating the intensity of serial correlation of residuals by including sufficient number of lags. Fourth, a simple linear transformation is used to develop error correction model (ECM) from ARDL model (Shrestha and Chowdhury, 2005). Last, in ARDL technique endogeneity problem does not creep in and therefore its estimates and tratios are unbiased and reliable. In this study we employed the ARDL suggested by Pesaran et al. (2001) to examine the relationship between economic growth and other variables.

In addition ARDL approach, the study adopts Toda and Yamamoto (1995) Granger causality test to improve results of the study. Different tests are available to identify the causality among the variables; such as Engle and Granger, 1987; Granger, 1969; Johansen and Juselius, 1990. These tests are not free from errors. They involve pre-testing for stationary and it is an essential to check the conintegration relationship. Further, they require selection of a maximum lag length and are highly sensitive with modal specification. To avoid these issues, this study employed a more robust causality model introduced by Toda and Yamamoto (1995). 


\section{Findings and Discussion}

To avoid spurious regression outcomes, it is important to confirm that none of the variables under consideration be integrated of order I (2) or higher before applying the ARDL bounds testing methodology to cointegration. Therefore, the Augmented Dickey-Fuller (ADF) unit root test is used to identify stationary of the variables. In addition, a PhillipsPerron (PP) test is also employed to confirm the ADF test result further.

Table 1 summarizes the results of the stationary tests in Singapore and Sri Lanka. The result presented in Tables 1 part I shows that all variables are stationary, either in levels or in the firstdifference level. The test results confirm that out of six, three of the variables are stationary in levels at the 1 percent level of significance for the ADF test, except government expenditure and government revenue. On the other hand, four of the variables are stationary in levels at the 5 percent level of significance for the PP test, except government revenue. Thus, Results reported in Table 1 are consistent with the null hypothesis that the variables are integrated of order one I (0) and I (1). However, both test results in Table 1 part II show that all the variables in Sri Lanka are stationary on their first difference I (1) at 1 percent of significant. The results confirm that there is no evidence to generate spurious estimation results between variables of these two countries since they become stationary at level or the first difference at 1 percent level of significance. These outcomes reveal that the ARDL bounds testing methodology to cointegration is appropriate to estimate the existence of long-run relationships for two countries.

Table 1 Results of Unit Root Test

\begin{tabular}{|c|c|c|c|c|}
\hline \multirow[t]{2}{*}{ Variable } & \multicolumn{2}{|c|}{$\begin{array}{c}\text { Augmented Dickey Fuller (ADF) } \\
\text { Test }\end{array}$} & \multicolumn{2}{|c|}{ Phillip-Perron (PP) Test } \\
\hline & Level & First-Difference & Level & $\begin{array}{c}\text { First- } \\
\text { Difference }\end{array}$ \\
\hline \multicolumn{5}{|c|}{ Singapore } \\
\hline $\log$ GDP (Y) & $-3.838897 * *$ & $-4.437832 * *$ & $-3.416480^{*}$ & $-4.427108 * *$ \\
\hline Log CPI (Y1) & $-4.337258 * *$ & $-7.565579 * *$ & $-3.864577 * *$ & $-7.678688^{* *}$ \\
\hline $\begin{array}{l}\text { Log Expenditure } \\
(\mathrm{Y} 2)\end{array}$ & -2.314688 & $-6.991925 * *$ & $-3.182264 *$ & $-6.992996 * *$ \\
\hline $\begin{array}{l}\text { Log Revenue } \\
\text { (LY3) }\end{array}$ & -1.134169 & $-6.835982 * *$ & -1.117183 & $-6.836503 * *$ \\
\hline $\begin{array}{l}\text { Log Investment } \\
\text { Expenditure (Y4) }\end{array}$ & -1.855160 & $6.835983 * *$ & -1.857373 & $-6.796354 * *$ \\
\hline $\begin{array}{l}\text { Log Defense } \\
\text { Expenditure (Y5) }\end{array}$ & $-4.128274 * *$ & $-4.637576 * *$ & $-11.92176 * *$ & $-4.545716^{* *}$ \\
\hline \multicolumn{5}{|c|}{ Sri Lanka } \\
\hline
\end{tabular}




\begin{tabular}{|l|c|c|c|c|}
\hline Log GDP (X) & -2.421382 & $-5.171372 * *$ & -2.049803 & $-5.272785^{* *}$ \\
\hline Log CPI (X1) & -1.455292 & $-4.708989 * *$ & -1.455292 & $-4.703213^{* *}$ \\
\hline $\begin{array}{l}\text { Log Expenditure } \\
(X 2)\end{array}$ & -1.998524 & $-8.593583 * *$ & $-3.012323 *$ & $-8.414937 * *$ \\
\hline Log Revenue (X3) & -1.229884 & $-7.571237 * *$ & -1.311129 & $-18.62140^{* *}$ \\
\hline $\begin{array}{l}\text { Log Investment } \\
\text { Expenditure (X4) }\end{array}$ & -0.141446 & $10.09839 * *$ & 0.160400 & $-9.640096^{* *}$ \\
\hline $\begin{array}{l}\text { Log Defense } \\
\text { Expenditure (X5) }\end{array}$ & -1.248038 & $-6.462010 * *$ & -1.284613 & $-6.462950^{* *}$ \\
\hline
\end{tabular}

Notes: For ADF and PP tests, ** and * denote rejection of a unit root hypothesis based on Mackinnon (1991) critical values at 1 percent and 5 percent, respectively.

\section{Source: Author Complied}

To evaluate the goodness of fit of the models, three tests are employed, that is, the Jarque-Bera normality test, the Breusch-Pagan-Godfrey test for heteroscedasticity and the BreuschGodfrey serial correlation LM test. The results of the estimated diagnostic tests for the ARDL approach as a cointegration model reflects a fairly high level of goodness of fit (refer Table 2). The results indicate that, no evidence of serial correlation and autoregressive conditional heteroskedasticity. The results also confirm that the residual terms are normally distributed. Thus, all diagnostic checks for the model reject the null hypothesis that the model is not the best fit.

Table 2 Diagnostic Tests Results

\begin{tabular}{|c|c|c|c|c|}
\hline \multirow{2}{*}{ Diagnostic tests indicators } & \multicolumn{2}{|c|}{ Model 1} & \multicolumn{2}{|c|}{ Model 3} \\
\hline & F-statistic & Prob. F & F-statistic & Prob. F \\
\hline \multicolumn{5}{|c|}{ Singapore } \\
\hline $\begin{array}{l}\text { Breusch-Godfrey Serial } \\
\text { Correlation LM Test }\end{array}$ & 0.749515 & 0.4876 & 1.004498 & 0.3768 \\
\hline $\begin{array}{l}\text { Heteroskedasticity Test: } \\
\text { Breusch-Pagan-Godfrey }\end{array}$ & 1.130231 & 0.4173 & 0.797714 & 0.5943 \\
\hline \multicolumn{5}{|c|}{ Sri Lanka } \\
\hline & \multicolumn{2}{|c|}{ Model 2} & \multicolumn{2}{|c|}{ Model 4} \\
\hline $\begin{array}{l}\text { Breusch-Godfrey Serial } \\
\text { Correlation LM Test }\end{array}$ & 0.011208 & 0.9889 & 1.536395 & 0.2316 \\
\hline $\begin{array}{l}\text { Heteroskedasticity Test: } \\
\text { Breusch-Pagan-Godfrey }\end{array}$ & 0.687204 & 0.7594 & 1.515034 & 0.1794 \\
\hline Normality test & J-B Statistic & Prob. & J-B Statistic & Prob. \\
\hline
\end{tabular}




\begin{tabular}{|l|l|l|l|c|}
\hline Singapore & $\begin{array}{l}0.396480 \\
(\text { Model 1) }\end{array}$ & 0.820173 & $\begin{array}{l}2.518644 \\
\text { (Model 3) }\end{array}$ & 0.283846 \\
\hline Sri Lanka & $\begin{array}{l}0.062873 \\
\text { (Model 2) }\end{array}$ & 0.969053 & $\begin{array}{l}0.494048 \\
\text { (Model 4) }\end{array}$ & 0.781122 \\
\hline
\end{tabular}

\section{Source: Author Complied}

In addition, in the consideration of above diagnostic tests Figures 3 to 6 present the stability test for the cumulative sum of recursive residuals (CUSUM) in the short and long run. According to the graphical illustration, CUSUM shows a satisfactory plot of the recursive residuals at the 95 percent significance level, which suggests that none of the parameters falls outside of the critically dotted lines. This suggests that long term coefficients are stable. In other words, four models are stable for the related period and have no any structural break as results of CUSUM.

Table 3 presents the result of the estimated ARDL bound test for cointegration in Singapore and Sri Lanka. The result confirms the existence of long- run cointegration among the estimated variables for Singapore and Sri Lanka under model 1 to 4 . The calculated $F$ statistics is 4.927206 in Singapore (Model 1) while 6.820512 in Sri Lanka (Model 2). These values are significance at 1 percent level which is greater than 4.37. Further, the results imply that the null hypothesis of $\mathrm{H} 0$ : no long-run relationship against its alternative $\mathrm{H} 1$ : long-run relationship is rejected on the basis of the critical values at the 1 percent significance level in Singapore and Sri Lanka for Model 3 and 4. Consequently, this finding reveal the existence of the long-run cointegrating relationships among GDP, fiscal policy variables and other macroeconomic variables over the period of 1972-2017 in Singapore and Sri Lanka.

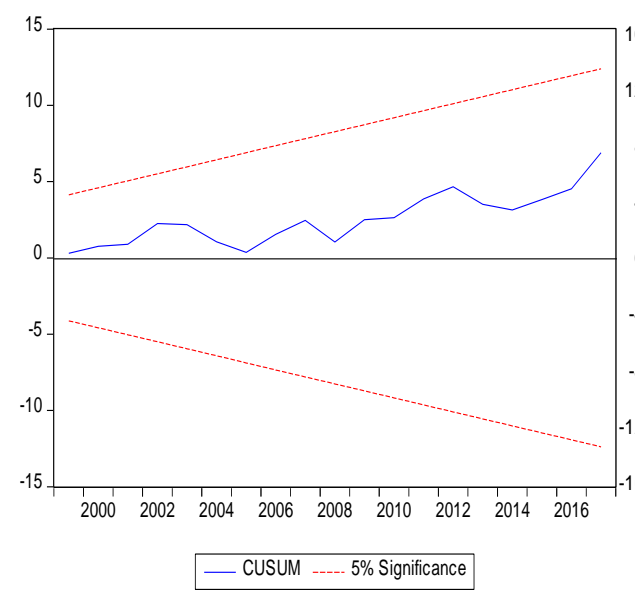

Figure 3 Model 1 -Singapore

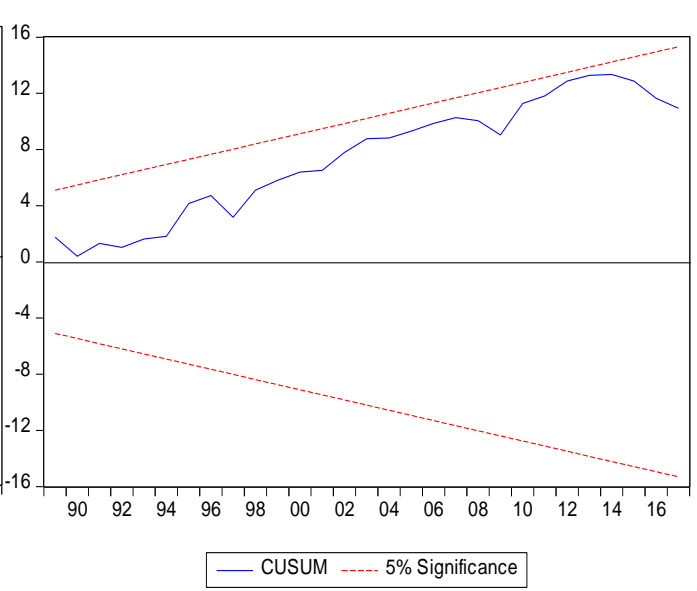

Figure 4 Model 2 -Sri Lanka 
Sriyalatha M.A.K., Torii H., KJM, 2019, 08 (01)

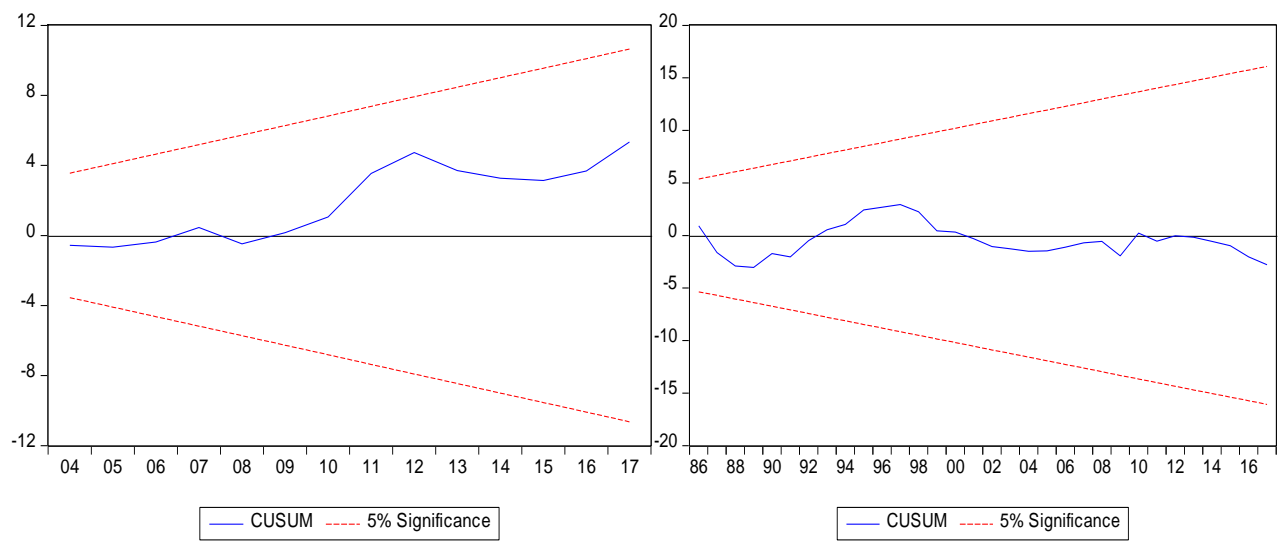

Figure 5: Model 3-Singapore $\quad$ Figure 6: Model 4-Sri Lanka Source: Author Complied

Table 3 Results of ARDL Bounds Test

\begin{tabular}{|c|c|c|c|c|c|}
\hline \multirow{2}{*}{} & \multicolumn{2}{|c|}{ Model } & \multicolumn{2}{c|}{ Critical Value (Pesaran et. al., 2001) } \\
\cline { 2 - 6 } & $\begin{array}{c}1 \& 2 \\
(\mathrm{k}=4) \\
\text { F-statistic }\end{array}$ & $\begin{array}{c}3 \& 4 \\
(\mathrm{k}=4) \\
\text { F-statistic }\end{array}$ & $\begin{array}{c}\text { Significance } \\
\text { Level }\end{array}$ & $\begin{array}{c}\mathrm{I}(0) \text { Lower } \\
\text { Bound }\end{array}$ & $\begin{array}{c}\text { I(1) } \\
\text { Upper } \\
\text { Bound }\end{array}$ \\
\hline Singapore & $4.927206 * * *$ & $8.372339 * * *$ & $10 \%$ & 2.2 & 3.09 \\
\hline Sri Lanka & $6.820512 * * *$ & $8.409604 * * *$ & $5 \%$ & 2.56 & 3.49 \\
\cline { 3 - 6 } & & & $1 \%$ & 3.29 & 4.37 \\
\hline
\end{tabular}

Note: ** denote critical values at 1 percent significance level.

Source: Author Complied 
Table 4 ARDL Long Run Estimates

\begin{tabular}{|c|c|c|c|c|c|}
\hline \multicolumn{6}{|c|}{ Singapore } \\
\hline \multicolumn{3}{|c|}{ Model 1} & \multicolumn{3}{|c|}{ Model 3} \\
\hline Variable & Coefficient & Prob. & Variable & Coefficient & Prob. \\
\hline LY1 & $-4.703785 * *$ & 0.0517 & LY1 & $-1.035622 * *$ & 0.0197 \\
\hline LY2 & $1.055274 * * *$ & 0.0023 & LY3 & $0.031165 * * *$ & 0.0000 \\
\hline LY3 & 0.704578 & 0.1433 & LY4 & $0.771406^{* * * *}$ & 0.0000 \\
\hline LY4 & $1.399118 * *$ & 0.0224 & LY5 & $0.621415^{* * *}$ & 0.0000 \\
\hline $\mathrm{C}$ & $-10.898278 * *$ & 0.0280 & $\mathrm{C}$ & $-2.014320 * * *$ & 0.0042 \\
\hline $\begin{array}{l}\text { CointEq } \\
(-1)\end{array}$ & $0.210617^{* * *}$ & 0.0000 & $\begin{array}{l}\text { CointEq(- } \\
\text { 1) }\end{array}$ & $1.386732 * * *$ & 0.0000 \\
\hline \multicolumn{6}{|c|}{ Sri Lanka } \\
\hline \multicolumn{3}{|c|}{ Model 2} & \multicolumn{3}{|c|}{ Model 4} \\
\hline Variable & Coefficient & Prob. & Variable & Coefficient & Prob. \\
\hline LX1 & $1.122512 * * *$ & 0.0000 & LX1 & $1.271294 * * *$ & 0.0000 \\
\hline LX2 & 0.078732 & 0.4176 & LX3 & $0.100145^{* *}$ & 0.0175 \\
\hline LX3 & 0.068824 & 0.1096 & LX4 & $0.334797 * * *$ & 0.0000 \\
\hline LX4 & $0.390000 * * *$ & 0.0000 & LX5 & $-0.070692 * *$ & 0.0161 \\
\hline $\mathrm{C}$ & $5.500971 * * *$ & 0.0036 & $\mathrm{C}$ & $9.306456 * * *$ & 0.0000 \\
\hline $\begin{array}{l}\text { CointEq( } \\
-1)\end{array}$ & $-0.625202 * * *$ & 0.0000 & $\begin{array}{l}\text { CointEq(- } \\
\text { 1) }\end{array}$ & $-0.616904 * * *$ & 0.0000 \\
\hline
\end{tabular}

Note: $* * * * *$ and $*$ denote critical values at 1 percent, 5 percent and 10 percent respectively.

\section{Source: Author Complied}

The ARDL long-run and Error Correction Model (ECM) estimated coefficients of inflation rate, government expenditure, government revenue, investment expenditure and defense expenditure are presented in Table 4 in Singapore and Sri Lanka under four models. The results confirm that government expenditure and investment expenditure are positive and statistically significant in Singapore while inflation rate and investment expenditure are positively related in Sri Lanka (see Model 1, 2 and 4). Since this model is specified in a log-linear form, the coefficient of the dependent variable can be interpreted as elasticity with respect to real GDP. In addition, Table 4 also indicates that inflation rate has a significant and negative long-run effect on Singapore's economy (refer Model 1).

Model 3 and 4 in Table 4 present results of disaggregate level data in Singapore and Sri Lanka. As for the effect of investment expenditure on economic growth, the results are positive and significant at 1 percent significance level for both countries at aggregate as well as disaggregate level. These results are consistent with Barro and Sala-i-Martin's (1995, 2003) findings. They pointed out 
that capital accumulation always enhances economic growth, which in turn further enriches the production of goods and services in the economy. Further, Bercuson et al. (1995) also have asserted that investment expenditure is the most important contributor to Singapore's economic growth.

Economic growth of a particular country is depends on monetary, fiscal and other economic policies undertaken by its policy makers and governments. Thus, economic growth is affected by a number of factors, one of which is inflation. Research studies have done for industrial and developed countries found a negative relationship between inflation and economic growth (Fisher (1993) Barro (1995) and Bruno and Easterly (1998)). On the other hand the empirical studies conducted for developing countries revealed a positive relationship (Mallik and Chowdhury (2001)). According to Model 1 and 3 for Singapore, the results find that there is a long-run negative relationship between growth rate and inflation rate. However, for Sri Lanka, the empirical evidence reveals that there is a long-run positive relationship between growth rates and inflation rate as found by (Mallik and Chowdhury (2001)). The results of Model 3 and 4 in Table 4, further reveals that expenditure on defense activities has positive significant impact on Singapore economy meanwhile negative impact on Sri Lankan economy. In addition, government revenue has positive significant impact on economic growth in two of comparable economies, Singapore and Sri Lanka.

The process of short-run adjustment is indicated by the error correction (EC) term lagged by a one period in Table 4 . In model 1 and 3 , coefficients of error correction term is 0.210617 and 1.386732 , respectively and is statistically significant at 1 percent level. The results show that the estimated value has not the hypothesized sign. In model 2, coefficient of error correction term is 0.625202 and is statistically significant at 1 percent level. This indicates that 63 percent of the disequilibrium of the previous period will be adjusted in current year in model 2. While in model 4 the estimated coefficient of EC is 0.616904 . It indicates that 62 percent of short run disequilibrium is eliminated in the current period. In conclusion, such a significant error correction term is an evidence of the existence of a stable, long-run relationship among the variables, or more specifically, fiscal policy variables as well as other macroeconomic variables and economic growth. 
Table 5 Granger Causality Test Result

\begin{tabular}{|c|c|c|}
\hline Null hypothesis $\left(\mathrm{H}_{0}\right)$ & $\begin{array}{c}\text { Wald statistics } \\
\text { (probability) }\end{array}$ & Conclusion \\
\hline Singapore & \multicolumn{2}{|c|}{ Model 1 (Lag 5) } \\
\hline LY2 does not cause LY & $11.53204^{* *}(0.0418)$ & $\mathrm{H}_{0}$ Rejected \\
\hline LY does not cause LY1 & $41.79363^{* * *}(0.0000)$ & $\mathrm{H}_{0}$ Rejected \\
\hline Singapore & \multicolumn{2}{|c|}{ Model 3 (Lag 4) } \\
\hline LY1 does not cause LY & $21.05402^{* * *}(0.0003)$ & $\mathrm{H}_{0}$ Rejected \\
\hline LY does not cause LY1 & $14.16644^{* * *}(0.0068)$ & $\mathrm{H}_{0}$ Rejected \\
\hline LY4 does not cause LY & $35.51700^{* * *}(0.0000)$ & $\mathrm{H}_{0}$ Rejected \\
\hline LY does not cause LY5 & $19.37708^{* * *}(0.0007)$ & $\mathrm{H}_{0}$ Rejected \\
\hline LY3 does not cause LY & $31.16703^{* * *}(0.0000)$ & $\mathrm{H}_{0}$ Rejected \\
\hline & \multicolumn{2}{|c|}{ Model 2 (Lag 4) } \\
\hline Sri Lanka & $15.80534 * * *(0.0012)$ & $\mathrm{H}_{0}$ Rejected \\
\hline LX does not cause LX4 & \multicolumn{2}{|c|}{ Model 4 (Lag 5) } \\
\hline \multicolumn{2}{|c|}{ Sri Lanka } & $\mathrm{H}_{0}$ Rejected \\
\hline LX4 does not cause LX & $12.08895^{* *}(0.0336)$ & $\mathrm{H}_{0}$ Rejected \\
\hline LX does not cause LX4 & $20.59509^{* * *(0.0010)}$ & \\
\hline
\end{tabular}

Source: Author Complied 
In addition, to confirm the results further, the Granger causality test based on Toda and Yamamoto (1995) is used to examine the causal relationship between variables. As already described above, all the variables are integrated at first order and lags length of the variables is selected based on AIC lag length selection criteria. The Granger causality test result is presented in Table 5. The results reveal that there is unidirectional causality among variables in Singapore and Sri Lanka except inflation rate in Model 3 and investment expenditure in Model 4. In Singapore, there is a bidirectional causal relationship between inflation rate and economic growth in Model 3 and for Sri Lanka, there is a bidirectional causal relationship between investment expenditure and economic growth for the sample period in Model 4. It means that inflation rate, investment expenditure and economic growth cause each other in Singapore and Sri Lanka.

\section{Conclusion}

This study is an attempt to empirically examine the long-run relationship and causal effects between fiscal policy variables as well as other macroeconomic variables and economic growth in Singapore and Sri Lanka using ARDL time series estimation. The results reveal that government expenditure, government revenue and investment expenditure have a long-run relationship with economic growth and its impact on economic growth is positive and significant in the case of Singapore and Sri Lanka. This implies that investment expenditure boosts growth of the country whereas a high inflation rate acts as a bottleneck on economic growth in Singapore. Further this result confirms the important role of fiscal policy in the case of Sri Lanka and Singapore; it is also consistence with the theory of Keynesian views.
The positive linkage between defense expenditure and economic growth is found in Singapore during the sample period. Yakovlev (2007) reveals that an increase in military expenditure causes to an expansion of new technology which creates spillover effect for the civilian sector of the economy. Wang et al. (2012) claim that military spending leads to enhance the economic fertility in OECD countries. Keynesian Theory reveals that when idle resources are available in the economy, the net effect of defense expenditures on growth is positive. Additionally, it assumes that the military expenditure is an important for safe environment for nation which is crucial for the efficient operation of markets.

Moreover, the findings show that defense expenditure has a negative impact on economic growth in the case of Sri Lanka. This finding is consistent with Sriyalatha (2009). Heo (1999) finds that military spending reduces investments and exports and subsequently hinders the economic growth. It means that there is an indirect negative effect from military spending to real income for South Korea. Mylonidis (2008) suggests that defense expenditure has negative impact on real income of the country. Since, Sri Lanka is a developing country military spending is constrained by the low income and growth. And also Sri Lanka is an arm importer which means military expenditures should be financed by the scarce resources and foreign exchange reserves of the country. So, only with a higher economic growth rate Sri Lanka can finance its military expenditures by themself and can have a positive effect with more sophisticated military technology and export capacity.

Granger causality test results indicate that there is unidirectional causality from government expenditure, investment expenditure and government revenue to economic growth in Singapore. This 
result is consistence with the theory of Keynesian views. Further, the result reveals that bidirectional relationship between inflation rate and economic growth in Model 3. Additionally, results reveal that there is a unidirectional causality from economic growth to defense expenditure in Singapore. This result is consistent with the findings of Topcu and Aras (2013). They claim that for Turkey, Brazil, China, and India; there is a unidirectional causality from economic growth to military expenditure. In the case of Sri Lanka, there is a bidirectional causal relationship between investment expenditure and economic growth for the sample period. In addition, the significantly high equilibrium error correction coefficient in Sri Lanka result comes with a correct sign. This implies a high speed of adjustment to equilibrium after a short-run disequilibrium.

The results of this study have important policy implications. Inflation rate has positive impact on economic growth in Singapore while negative impact exhibits for Sri Lanka. Inflation is helpful rather than harmful to growth for developing countries, and faster economic growth is likely to be inflationary. This finding is consistent with Mallik and Chowdhury (2001). Many economists, businessmen, and politicians believe that moderate inflation levels are needed to drive consumption. When the economy is not running at full capacity, meaning there is unused resources, inflation theoretically helps increase production. More money translates to more spending, which equates to more aggregated demand. More demand, in turn, triggers more production to meet that demand. Specially, Sri Lanka need inflation for growth, but too fast a growth rate may accelerate the inflation rate and take them downhill as revealed by Bruno and Easterly (1998). Barro (1995) explained the fact that high level of inflation discourages the level of investment and such negative impact adversely affects economic growth.

The results find that there is a long-run negative relationship between growth rate and inflation rate in Singapore. This finding is consistent with the results of Fisher (1993), Barro (1995) and Bruno and Easterly (1998). They find that for industrial and developed countries, there is a negative relationship between inflation rate and economic growth.

\section{References}

Alexander A.M.O (1990) Public Expenditure and Economic Growth: The Case of Developing nation, Journal of Sustainable Development, 2: 56-101

Attari M. I.J and Javed A.Y (2013) Inflation, Economic Growth and Government Expenditure of Pakistan: 1980-2010, Procedia Economics and Finance, 5: $58-67$

Barro, R. J. (1995) Inflation and Economic Growth, NBER Working Paper No. 5326

Barro, R. J. and Sala-i-Martin, X. (1995) Economic Growth, McGraw-Hill, New York, NY

Barro, R., (1996) "Inflation and growth", Federal Reserve Bank of St. Louis Review, 78, 153-169

Barro, R.J. and Sala-i-Martin, X. (2003) Economic Growth, 2nd ed., ISBN 9780262025539, MIT Press, MA

Bercuson, K., Carling, R.G. and International Monetary Fund (1995) Singapore - A Case Study in Rapid Development, International Monetary Fund, Washington, DC. 
Bruno, M. and W. Easterly, (1998) "Inflation crises and Long-run Growth", Journal of Monetary Economics, 41, 3-26

Central Bank Annual Report, (2016) Sri Lanka

Cheung, Y. W. and Lai, K. (1993) "A fractional Cointegration analysis of Purchasing Power Parity", Journal of Business \& Economic Statistics, Vol. 11, pp. $103-112$

Deverajan S, Swaroop V. and Zou Heng -Fu (1996) The Composition of Public Expenditure and Economic Growth., Journal of Monetary Economics, 37 (23): 313-344

Economic Survey of Singapore (2017) Ministry of Trade and Industry Singapore

Engle, F.R. and Granger, C. J. (1987) "Co-integration and Error Correction: representation, estimation, and testing", Econometrica, 55 (2), 251-276

Fischer, S., (1993) The role of Macroeconomic factors in growth, NBER Working Paper No. 4565

Granger, C.W.J. (1969) "Investigating Causal relations by Econometric models and cross spectral methods", Econometrica, 37, 424-438

Heo, U. (1999) Defense spending and Economic Growth in South Korea: The indirect link. Journal of Peace Research, 36(6), 699-708

Hirnissa M.T., Habibullah M.S. and Baharom A.H. (2009) Military Expenditure and Economic Growth in Asean-5 Countries, Journal of Sustainable Development, 2 (2), 192- 202

Iulia Rosoiu (2015) The impact of the Government Revenues and Expenditures on the Economic Growth, Journal of Sustainable Development, 32: 526 - 533

Johansen, S. and Juselius, K. (1990) "Maximum Likelihood estimation and inference on Cointegration with applications to the Demand for Money", Oxford Bulletin of Economics and Statistics, 52 ( 2), 169-210

Johansen, S., (1988) Statistical analysis of Co-integrated Vectors, Journal of Economic Dynamics \& Control, 12(2-3): 231-254

Johansen, S.,( 1991) Estimation and Hypothesis Testing of Cointegration Vectors in Gaussian Vector Autoregressive Models, Econometrica, 59 (6): 1551-1580

Keynes J. M (1936) General Theory of Employment, Interest and Money, London: Palgrave MacMillan, UK

Liu C, Hsu C, Younis M. Z (2008) The Association between Expenditure and Growth: The Granger causality test of the US data. 1974-2002. Journal of Public Budgeting, Accounting and Financial Management, 20: 439-452

Mallik, G. and Chowdhury, A., (2001) Inflation and Economic Growth: Evidence from South Asian Countries, Asian Pacific Development Journal, 8, (1) :123- 135

Mohammadi H. and Ram R. (2015) Economic Development and Government Spending: An Exploration of Wagner's Hypothesis during Fifty Years of Growth in East Asia, Economies, 3, 150-160

Mylonidis, N. (2008) Revisiting the nexus between Military Spending and Growth in the European Union. Defense and Peace Economics, 19(4), 265-272 
Ono H. (2014) The Government Expenditure-Economic Growth relation in Japan: an analysis by using the ADL test for threshold Co-integration, Applied Economics, 46 (28), 3523 -3531

Phuc Canh N. (2018) "The effectiveness of fiscal policy: contributions from institutions and external debts", Journal of Asian Business and Economic Studies, 25

(1):50-66 https://doi.org/10.1108/JABES-05-20180009

Pesaran, H. Shin, Y. and Smith, R. (2001) Bound testing approaches to the analysis of level relationships, Journal of Applied Econometrics, 16, 289-326

Peacock A. T, Wiseman J (1961) The Growth of Public Expenditure in the United Kingdom. Princeton: Princeton University Press, UK

Shrestha, M.B. and K. Chowdhury, (2005) ARDL modeling approach to testing the financial liberalization hypothesis, Working Paper 05-15 (Department of Economics, University of Wollongong)

Solow R (1956) A Contribution to the Theory of Economic Growth, Quarterly Journal of Economics 70: 65-94

Solow R (1957) Technical Change and Aggregate production function, Review of Economics and Statistics 39: 748-62

Sriyalatha M.A.K (2009) Defense Expenditure and Economic Growth: Granger Causality Evidence from Sri Lanka, Proceedings of the Sixth International Conference on Business Management, University of Sri Jayewardenepura, Sri Lanka

Sriyalatha M.A.K (2012) Causality Testing and Wagner's Law: The Case of
Sri Lanka. Sri Lanka Journal of Business Economics, 3 (1): 47-56

Toda, H.Y. and Yamamoto, T. (1995) "Statistical inference in Vector Autoregressions with possibly integrated processes", Journal of Econometrics, 66 (1-2), 225-250

Topcu, M., Aras, I.(2013) Economic impacts of Military Expenditures: a comparative analysis on superpowers of the World, Actual Problems of Economics, 142 (4), 495-506

Wagner, A. (1883) Three Extracts on Public Finance, in R. A. Musgrave and A. T. Peacock eds 1958. Classics in the Theory of Public Finance, London: Macmillan

Wang, T. P., Shyu, S. H. P., Chou, H. C. (2012) The impact of Defense Expenditure on Economic Productivity in OECD countries, Economic Modeling, 29(6), 2104-2114

Yakovlev, P. (2007) Arms trade, Military Spending, and Economic Growth, Defense and Peace Economics, 18(4), 317-33 